\title{
DIREITOS FUNDAMENTAIS NA CONSTITUIÇÃO DE 1988 E INCORPORAÇÃO, AO DIREITO BRASILEIRO, DE TRATADOS INTERNACIONAIS A ELES RELATIVOS*
}

\author{
FUNDAMENTAL RIGHTS AND THE INCORPORATION OF INTERNATIONAL TREATIES ABOUT
}

FUNDAMENTAL RIGHTS IN BRAZILIAN LAW

Fernando Dias Menezes de Almeida**

\begin{abstract}
Resumo:
Este artigo tem por objetivo apresentar uma visão geral e evolutiva sobre a disciplina constitucional dos direitos fundamentais no Brasil, com foco especial nos direitos originários de tratados internacionais e as mudanças recentes do entendimento do Supremo Tribunal Federal quanto à sua hierarquia.
\end{abstract}

Palavras-chaves:

\begin{abstract}
:
This paper aims to present a general and evolutive view of the constitutional discipline of fundamental rights in Brazil, with a special focus on the rights originated from international treaties and the recent changes in Supremo Tribunal Federal position regarding their hierarchy.
\end{abstract}

Keywords:

1. Aspectos históricos

Sob evidente influência do constitucionalismo contemporâneo, de matriz francesa, desde sua primeira Constituição como País independente - ou seja, a Constituição Imperial de 1824 - o Brasil acolhe expressamente um rol de liberdades fundamentais.

Os juristas e governantes brasileiros daquele momento eram bastante atentos à síntese do espírito do constitucionalismo contida no art. 16 da Declaração dos Direitos do Homem e do Cidadão, de 1789:

Toute Société dans laquelle la garantie des Droits n'est pas assurée, ni la séparation des Pouvoirs déterminée, n'a point de Constitution.

É certo, como veremos na sequência desta exposição, que o rol de liberdades fundamentais no Brasil - e o fenômeno não é apenas brasileiro - sofre ao longo dos séculos XIX e XX uma larga evolução, passando a acolher outros direitos que, de rigor, iriam além do sentido tradicional de "liberdades".

* $\quad$ Este texto foi a base de aula ministrada pelo Autor, como professor visitante, na Universidade de Lyon 3 (Jean Moulin), França, em janeiro de 2012.

** $\quad$ Professor Associado da Faculdade de Direito da Universidade de São Paulo 
Desse modo, torna-se mais usual na linguagem constitucional brasileira de hoje falar-se mais amplamente em direitos fundamentais.

Suponho que seja pouco interessante para uma audiência francesa um relato mais detalhado de como as diversas Constituições brasileiras trataram das liberdades ou direitos fundamentais desde 1824 .

Pretendo, pois, deter-me em aspectos da Constituição vigente. No entanto, de modo muito breve pareceu-me oportuno apresentar uma visão panorâmica sobre a evolução constitucional e, ao mesmo tempo, política, brasileira.

O Brasil, até hoje, teve sete Constituições. Para dizer apresentar esse número, estou considerando a compreensão política de qual seria uma "nova" Constituição.

Isso porque, pelo estrito sentido jurídico, talvez pudéssemos considerar certas Constituições como verdadeiras emendas de Constituições anteriores - tal como se passa com a vigente Constituição de 1988, a qual foi elaborada por Assembléia Constituinte convocada por emenda à Constituição anterior, emenda essa que já impôs certos limites de conteúdo e de procedimento aos trabalhos constituintes.

Do mesmo modo, talvez pudéssemos considerar outros documentos jurídicos, que não passaram para a história denominados "Constituições", como reais atos de ruptura com a ordem constitucional então vigente. São exemplos de atos desse tipo os atos eufemisticamente ditos "institucionais" ou "complementares", decretados pela chefia do Poder Executivo, e que amplamente afastavam a incidência das regras constitucionais vigentes no período do governo militar havido de 1964 a 1985.

Mas voltemos ao ponto em que dizia que o Brasil teve, até hoje, sete Constituições.

A primeira foi, como já mencionado, a Constituição Imperial de 1824, outorgada pelo Imperador Pedro I, futuro Rei Pedro IV de Portugal. Essa Constituição estabeleceu um regime monárquico no qual o imperador, ainda que submetido ao Direito, gozava de uma situação privilegiada nos seguintes termos:

Art. 99. A Pessoa do Imperador é inviolável, e Sagrada: Ele não está sujeito a responsabilidade alguma.

E mais, era o titular do Poder Moderador que, em suma, dava-lhe uma preponderância sobre os demais Poderes constituídos. Registre-se que Pedro I exerceu um governo de caráter mais autoritário que seu filho e sucessor Pedro II. Este último governou o Brasil por 58 anos, sendo reconhecido pela história como um monarca zeloso das liberdades constitucionais e comedido no uso de seus poderes.

Com a proclamação da república, em 1889, o Brasil viu surgir sua segunda Constituição em 1891. Trata-se de uma Constituição tipicamente liberal, bastante influenciada pelo pensamento e pela prática institucional norte-americana, notadamente quanto à forma federativa de Estado e quanto ao sistema de jurisdição unificada. 
O regime liberal do período que ficou conhecido como "República Velha" encerrou-se em 1930, com o golpe de Estado dado por Getúlio Vargas, com forte apoio militar e das elites de diversos Estados federados - praticamente com a exceção de São Paulo. Note-se que Vargas, que fora ministro das finanças do governo anterior, candidatarase à sucessão presidencial, perdendo as eleições populares.

O governo Vargas, que marcou profundamente a história do Brasil, é um dos períodos mais repletos de polêmicas e de interpretações contraditórias, até os dias de hoje.

Vargas governou o Brasil de 1930 a 1945, sem ter sido eleito em eleições populares, em grande parte desse período com poderes ditatoriais. Retornou ao governo em 1951, agora eleito em eleições populares e livres, tendo cometido suicídio em 1954, em meio a intensa batalha política com partidos de oposição, que acusavam seu governo de atos autoritários e atentatórios contra a liberdade e a vida de opositores.

Vargas, é certo, promoveu em grande medida a modernização e a industrialização do País e introduziu na legislação um sistema de proteção aos direitos dos trabalhadores que vigora até hoje. Por esse fato, era tratado popularmente como o "Pai dos Pobres". Por outro lado, praticamente anulou as liberdades individuais e a independência dos demais Poderes. E, dizem os analistas da história, por muito pouco não aliou o Brasil às forças nazistas na Segunda Guerra - após a negociação com os Estados Unidos da América, em torno de certos investimentos industriais no Brasil, o País juntou-se às forças aliadas.

Durante a era Vargas, o Brasil teve duas Constituições. A primeira delas, em 1934, foi resultado de uma verdadeira guerra civil (a Revolução Constitucionalista), iniciada pelas forças do Estado de São Paulo em defesa da adoção de um regime constitucional e garantidor de liberdades: eis que Vargas, desde o golpe de 1930, governava sem uma Constituição. Com a derrota das forças revolucionárias, Vargas ainda assim habilmente fez concessões à elite paulista - que já concentrava o poder econômico no País - e convocou uma assembléia constituinte livremente eleita.

A Constituição dela decorrente, em 1934, já sofreu a grande influência da Constituição Alemã de 1919 (Weimar), acolhendo rol de direitos econômicos e sociais, ao lado das clássicas liberdades públicas.

Mas a Constituição de 1934 teve vida efêmera, sendo substituída pela Constituição de 1937, em um movimento que caracterizou novo golpe de Estado: foram canceladas as eleições presidenciais, foi fechado o Parlamento e outorgada, pelo Presidente Vargas, a nova Constituição, apelidada de "Polaca", vez que sofreu forte influência da Constituição polonesa de então, de índole autoritária.

Com a redemocratização do País, após o fim do primeiro governo Vargas, uma Assembléia, fruto de eleições populares, elaborou a Constituição promulgada em 1946. Retomava-se a normalidade institucional, sob um regime representativo, com clara 
garantia de direitos (liberdades públicas e direitos econômicos e sociais) e separação de Poderes.

Um novo ciclo de regimes autoritários inicia-se em 1964, com a tomada do poder por forças militares, alegadamente num movimento contrário a uma eventual revolução socialista de inspiração soviética.

O regime militar, que inicialmente mantém em vigor a Constituição de 1946 e convoca para breve novas eleições populares sofre, no ano seguinte, um retrocesso. Sob o comando de um setor militar de linha mais autoritária, são canceladas as eleições diretas para presidente da república e o Congresso Nacional, sob forte ingerência do Poder Executivo, edita nova Constituição, em 1967.

Formalmente, a Constituição de 1967 mantém um regime de liberdades e separação de Poderes. Todavia, todo sistema jurídico de exceção foi ditado por atos ditos "institucionais" ou "complementares", que, invocando o poder constituinte originário, personificado pelo comando da revolução, criava amplas restrições ao texto constitucional, praticamente eliminando a garantia de liberdades (sobretudo de cunho político) e estabelecendo uma evidente predominância do Poder Executivo sobre os demais Poderes constituídos.

Com o fim do regime militar, em 1985, num movimento pacífico e conduzido pelas próprias lideranças militares em entendimentos com setores da oposição mais moderada, inaugura-se nova fase de abertura democrática. Seu marco constitucional é a Constituição Federal de 1988, ainda em vigor.

\section{Direitos fundamentais na Constituição de 1988}

Com forte carga simbólica, a Constituição de 1988 foi a primeira a trazer o rol de direitos e garantias fundamentais para seu início - quando, na tradição brasileira, os respectivos artigos situavam-se topicamente ao final do texto constitucional.

Nesse sentido, após a apresentação de seus "princípios fundamentais”, nos quatro artigos iniciais, a Constituição traz um longo artigo $5^{\circ}$, composto de 78 "incisos" (e muito desses incisos subdivididos em "alíneas"), numa que talvez seja a mais extensa (ou prolixa) declaração de direitos do constitucionalismo contemporâneo. ${ }^{1}$ Isso sem contar mais aproximadamente 3 dezenas de dispositivos tratando de direitos sociais (arts. $6^{\circ}$ a 11 ) e capítulos inteiros dedicados a temas específicos, que igualmente importam direitos, tais como "saúde", "educação", "previdência social”, "ordem tributária”.

\footnotetext{
Aliás, sem contar os respectivos "blocs de constitutionalité", numa comparação do tamanho dos textos das Constituições brasileira e francesa, a francesa tem aproximadamente 11.000 palavras, enquanto a brasileira tem aproximadamente 74.000 !
} 
Além desses direitos, que a doutrina convencionou chamar de "primeira" e "segunda geração", a Constituição brasileira acolheu expressamente os direitos de "terceira geração", no sentido de direitos transindividuais, que remetem à preservação da humanidade como um todo. Podem ser citados como exemplos desses últimos o direito ao meio ambiente ecologicamente equilibrado e diversos princípios que regem as relações internacionais do Brasil, como o direito à paz, o direito à autodeterminação dos povos. - O tema dos princípios de regência das relações internacionais do Brasil, aliás, é tema de predileção do Prof. Celso Lafer, que certamente vai desenvolvê-lo por ocasião de sua lectio magistralis, ao receber, em breve, o Doctorat Honoris Causa desta prestigiosa Universidade.

Coexistem, pois, no rol contido na Constituição brasileira direitos e liberdades:

a) mais abrangentes e tradicionais: ex.: direito à vida, liberdade corporal, direito à igualdade, direito de propriedade, direito à segurança;

b) mais específicos, ainda de primeira geração: ex.: liberdade de manifestação de pensamento, liberdade de associação, liberdade de reunião, inviolabilidade de domicílio;

c) de cunho político: ex.: direito ao voto, liberdade de criação e filiação a partidos políticos, plebiscito, referendo;

d) que configuram desdobramentos da liberdade corporal em matéria penal, ou da propriedade, em matéria tributária;

e) de caráter econômico e social: ex.: direito à saúde, direito à educação, liberdade de empresa, direito à moradia, direito à proteção da relação de trabalho, direito à previdência social;

f) de terceira geração, como acima já exemplificado;

g) estruturantes do sistema jurisdicional de garantias: ex.: direito ao devido processo legal, inafastabilidade do controle judicial, proteção aos direitos adquiridos;

h) de caráter instrumental, no sentido de medidas judiciais de garantia de outros direitos e liberdades: ex.: habeas corpus, mandado de segurança, ação civil pública;

i) de caráter (exageradamente) específico, que até causam estranheza ao leitor do texto constitucional por estarem topicamente citados na mesma situação de outros tão amplos: ex.: direito das presidiárias de amamentarem seus filhos enquanto estiverem cumprindo pena de prisão, direito à obtenção de certidões isentas de taxas, direito dos criadores e intérpretes a fiscalizar o aproveitamento econômico das obras que criarem ou de que participarem. 
3. Algumas peculiaridades do regime jurídico constitucional dos direitos fundamentais

Feita essa ilustração exemplificativa da previsão de direitos fundamentais na Constituição brasileira vigente, verifiquem-se agora algumas regras peculiares ao regime jurídico desses direitos. Chamo atenção especialmente para três delas.

3.1. Limite material ao poder de revisão constitucional

Em primeiro lugar, uma regra relativa aos limites materiais ao poder de revisão constitucional.

Essa matéria é tratada no art. $60, \S 4^{\circ}$, da Constituição:

$\S 4^{\circ}$ - Não será objeto de deliberação a proposta de emenda tendente a abolir:

I - a forma federativa de Estado;

II - o voto direto, secreto, universal e periódico;

III - a separação dos Poderes;

IV - os direitos e garantias individuais.

Desse dispositivo decorrem quatro questões principais:

a) a expressão "direitos e garantias individuais" não corresponde exatamente a nenhum título específico da Constituição. A que normas constitucionais, portanto, ela remeteria?

$\mathrm{O}$ art. $5^{\circ}$ da Constituição que, como visto, traz concentradamente um rol de direitos fundamentais, refere-se a "direitos e deveres individuais e coletivos". Os “coletivos" estariam excluídos do limite ao poder de revisão?

Por outro lado, há direitos e garantias individuais fora do art. $5^{\circ}$, como igualmente já mencionado. Esse limite ao poder de revisão abrangeria os direitos sociais, os direitos decorrentes do sistema tributário, entre outros?

Sobre essa questão, a doutrina e a jurisprudência brasileiras, pacificamente, entendem que a expressão "direitos e garantias individuais" quer remeter amplamente à noção de "direitos fundamentais".

b) e qual seria o alcance da expressão "tendente a abolir"?

Note-se que não há um limite a "qualquer alteração" no regime constitucional, mas sim limites a alterações que "tendam a abolir" direitos fundamentais.

Mas o que seria uma tendência de abolição? A adoção de um regime mais restritivo? Por um lado, a restrição pode ser uma tendência à abolição; por outro, pode ser uma necessária adaptação à realidade, sob pena de, não havendo tal adaptação, a realidade impor, de fato, a supressão de um direito inflexível e anacronicamente previsto. 
Parece-me razoável entender que a tendência a abolir não se verifica com a simples mudança de regime, ainda que mais restritiva, até porque muitas vezes a ampliação (protetiva) do regime de um direito fundamental pode automaticamente significar uma movimento restritivo do regime de outro. Tal se passa, por exemplo, com a extensão da garantia do direito ao meio ambiente em confrontação com o regime do direito de propriedade.

c) e o que não se poderia abolir: cada norma específica sobre direitos fundamentais?; ou cada direito isoladamente considerado?; ou o conjunto dos direitos fundamentais?

Em que pese a questão hipotética, não se registram no Brasil opiniões mais enfáticas no sentido de que a o limite constitucional refira-se ao conjunto dos direitos fundamentais. Ou seja, entende-se que o limite refere-se a cada direito. Caso contrário, direitos poderiam ser suprimidos, desde que um rol mínimo de direitos permanecesse existindo.

De outro lado, parece-me sim razoável interpretar a Constituição nos sentido de que aquilo que se quer limitar não é a supressão de determinado dispositivo (quero dizer, de determinado enunciado textual: artigo, parágrafo, inciso, alínea), mas sim a supressão de determinado direito. Por exemplo: o direito de associação vem tratado em 5 incisos do art. $5^{\circ}$; e o que se quer vedar é a supressão do direito de associação e não de um dos eventuais incisos que dele cuidam.

d) e uma quarta questão: essa regra sobre os limites materiais ao poder de revisão constitucional seria ela mesma um limite ao mesmo poder de revisão? Por outras palavras, poderse-ia suprimir a regra que impede a supressão de direitos fundamentais, ou expressamente criar exceção a ela, para depois suprimir certo direito?

A tese da dupla revisão - acolhida, aliás, por clássicos autores franceses, como Duguit, Burdeau e Vedel - parece-me correta. Antes de mais nada, ele importa respeito à liberdade de decisão política das futuras gerações.

Contudo, esse não é um assunto pacífico na doutrina, nem discutido na jurisprudência brasileiras.

Na verdade, não suponho que, na prática, alguém algum dia pretendesse, por emenda constitucional, suprimir a regra que veda a supressão dos direitos fundamentais.

Nem conheço, concretamente, exemplos de tentativa de supressão de direitos isolados, mediante prévia introdução de exceção à regra do art. $60, \S 4^{\circ}$.

Por outro lado, há sim exemplos concretos de emendas constitucionais que alteraram o regime de certos direitos, como se passou, no caso do regime previdenciário, com a introdução da contribuição a ser paga por servidores públicos já aposentados.

Nesse caso, não se argumentou que houvesse um direito fundamental dos aposentados ao não pagamento de contribuição previdenciária, direito esse eventualmente 
abolido por emenda constitucional. Mas argumentou-se sim que essa emenda constitucional teria sido "tendente a abolir" o direito fundamental aos direitos adquiridos.

No entanto, prevaleceu na jurisprudência constitucional brasileira o entendimento de que não há direito adquirido oponível à mudança da norma constitucional. De todo modo, nesse caso concreto, a discussão judicial transitou mais pela noção sempre polêmica - de direito adquirido, do que pelo alcance da regra do art. $60, \S 4^{\circ}$.

\subsection{Aplicabilidade imediata}

Em segundo lugar, queria destacar a previsão constitucional contida no $\S 1^{\circ}$, do art. $5^{\circ}$, da Constituição:

\section{$\S 1^{\circ}$. As normas definidoras dos direitos e garantias fundamentais têm aplicação imediata.}

Ora, esse parece um enunciado de suficiente clareza. Todavia, não é isento de polêmica. Até porque, como bem observa entre nós Manoel Gonçalves Ferreira Filho, ${ }^{2}$ uma norma constitucional só tem aplicação imediata se for completa.

Abordado o problema de outro ângulo, pode-se dizer que ter ou não aplicação imediata é algo que depende da realidade factual (decorre do "mundo do ser", para usar a clássica expressão de Kelsen). Não basta o legislador afirmar que uma norma seja autoexecutável se, de fato, ela não possui elementos suficientes para se executar.

No entanto - talvez consciente de que as normas não têm aplicação imediata tão somente a partir da "mágica" afirmação de que a devam ter - o constituinte previu na Constituição brasileira a seguinte ação judicial:

\section{Art. $5^{\circ}$, LXXI - conceder-se-á mandado de injunção sempre que a falta de norma regulamentadora torne inviável o exercício dos direitos e liberdades constitucionais e das prerrogativas inerentes à nacionalidade, à soberania e à cidadania;}

Ou seja, caso um direito fundamental não se possa imediatamente aplicar por uma insuficiência normativa, poderá a pessoa interessada ajuizar mandado de injunção, para obter dos tribunais uma tutela específica de seu direito.

Ocorre que, desde 1988, até 2007, a jurisprudência do Supremo Tribunal Federal (STF) era no sentido de, ao julgar procedente um mandado de injunção, tão somente dar ciência ao legislador quanto à sua omissão, sem maiores conseqüências. Quando muito, o STF abria a possibilidade de que tribunais e juízes de instâncias inferiores diretamente fixassem medida concreta de caráter indenizatório.

2 FERREIRA FILHO, Manoel Gonçalves. Curso de direito constitucional. 37. ed. São Paulo: Saraiva, 2011. p. 340 . 
Porém, em 2007 houve dois julgamentos inovadores ${ }^{3}$. Tratava-se do exercício do direito de greve dos servidores públicos, direito esse constitucionalmente afirmado, mas condicionado à edição de lei regulamentadora que até hoje não existe.

Nesses casos, o STF, modificando seu entendimento anterior, por meio do mandado de injunção efetivamente criou normas gerais e abstratas - como se fosse legislador - para reger o exercício do direito em questão.

Como desde então não houve outros julgamentos desse porte pelo STF, talvez ainda seja prematuro dizer que se trata de definitiva alteração no entendimento jurisprudencial. Pode-se, de todo modo, apontar essa tendência.

Entretanto, ainda em matéria de aplicabilidade imediata dos direitos fundamentais, especialmente dos direitos sociais - p. ex., direito à saúde, à educação, à moradia - outro fenômeno relativamente recente detectado na jurisprudência brasileira é o do dito "ativismo judicial".

Em breves palavras, muitos juízes e tribunais, ante a constatação da ineficiência governamental, apreciando ações coletivas, de iniciativa do Parquet ou de associações legitimadas, ou mesmo apreciando pedidos formulados em ações individuais, condenam concretamente o Estado a pagar determinado remédio prescrito por médico particular; ou a pagar certo tratamento médico em hospital privado ou no exterior; ou a construir escolas em determinada localidade; ou a construir moradias.

Enfim, trata-se de uma intervenção do Poder Judiciário em assuntos que tradicionalmente seriam considerados de competência da Administração, valendo-se de seu juízo político discricionário.

E uma intervenção que me parece muito exagerada, indo muito além do que seria razoável supor em termos da tutela jurisdicional dos direitos individuais.

Aliás, o problema, em essência, considero ser justamente dar-se um tratamento individual a situações que só podem ser resolvidas numa ótica coletiva. É o problema, enfim, de tomar os direitos sociais pela ótica puramente individual.

Assim, no momento em que um juiz condena o Estado a fornecer um remédio inovador, supostamente mais eficaz, porém muitas vezes mais caro, para doente que poderia ser eficientemente tratado por remédio mais barato e comprovadamente eficaz e distribuído regularmente pelo sistema público de saúde, esse mesmo juiz não dimensiona que, na outra ponta, faltarão recursos para o atendimento de diversos outros doentes ou para ações de medicina preventiva.

Esse exemplo dos medicamentos é o que no momento se torna mais grave no Brasil, comprometendo severamente o planejamento orçamentário de muitos Estados e Municípios. Isso sem falar em denúncias já comprovadas de fraudes na prescrição de

MI 670, Rel. Min. Gilmar Mendes, j. 25.10.07; e MI 712, Rel. Min. Eros Grau, j. 25.10.07. 
medicamentos "incentivada" pela indústria farmacêutica, ou mesmo de casos de corrupção judicial.

Até compreendo que o Poder Judiciário possa condenar o Administrador Público a adotar alguma política de garantia do acesso à moradia ou à educação. Mas não faz sentido que, ultrapassando todo mecanismo democrático de eleições populares do Administrador e de controle parlamentar do orçamento, o Judiciário dite especificamente quais as medidas concretas que devam ser tomadas.

\subsection{Direitos fundamentais implícitos}

A terceira regra peculiar ao regime jurídico dos direitos fundamentais que gostaria de destacar diz respeito à previsão de direitos implícitos:

Art. $5^{\circ}$. [... $§ 2^{\circ}$. Os direitos e garantias expressos nesta Constituição não excluem outros decorrentes do regime e dos princípios por ela adotados, ou dos tratados internacionais em que a República Federativa do Brasil seja parte.

Esse dispositivo alcança direitos de duas fontes: de um lado, direitos que se considerem implícitos do que genericamente se diz "regime" constitucional, ou dos princípios previstos na Constituição; de outro, direitos decorrentes de tratados internacionais.

Quanto à regra dos implícitos - salutar, admita-se, do ponto de vista da garantia de direitos - parece-me que deva ser compreendida mais como uma norma de interpretação do que pela literalidade de seu texto.

Explico melhor: dada a prodigalidade com que se afirmaram e se particularizaram direitos na Constituição brasileira, somados a eles os direitos decorrentes explicitamente de tratados internacionais, é difícil algum direito não previsto e que haja de ser assegurado como "direito implícito". Francamente, não consigo pensar em um exemplo, nem encontrá-lo na doutrina.

Portanto, a utilidade dessa regra não está, penso eu, na sua literalidade. Não se trata de tipificar "outros" direitos decorrentes do regime ou dos princípios constitucionais; mas sim de uma diretriz para que se interpretem ampliativamente o regime e os princípios constitucionais.

Note-se que a Constituição brasileira não contém dispositivo semelhante ao preâmbulo da Constituição francesa, invocando precedentes declarações de direitos, ou algum documento internacional específico. Mas isso não impede que parte da doutrina brasileira invoque a noção de bloco de constitucionalidade, como a seguir será visto em matéria de direitos decorrentes de tratados internacionais.

Quanto à regra atinente aos tratados internacionais, dado seu interesse específico para o estudo comparativo, passo a comentá-la de modo mais detido. 
4. Incorporação dos tratados internacionais ao Direito brasileiro. O caso dos tratados sobre direitos fundamentais

Não tenho a intenção de fazer aqui uma exposição aprofundada de Direito internacional. Apenas recordarei os pontos principais, chamando atenção para algumas decisões do Supremo Tribunal Federal (STF).

Nesse contexto, a posição adotada no julgamento da ADI-MC $1.480,{ }^{4}$ bem como em outros casos precedentes ou subsequentes, é emblemática. Por meio dessa ação, questionava-se a constitucionalidade de dispositivos da Convenção n. 158 da Organização Internacional do Trabalho. Nessa ocasião ficou assentado, nos termos da ementa do acórdão:

a) PROCEDIMENTO CONSTITUCIONAL DE INCORPORAÇÃO DOS TRATADOS OU CONVENÇÕES INTERNACIONAIS - É na Constituição da República - e não na controvérsia doutrinária que antagoniza monistas e dualistas - que se deve buscar a solução normativa para a questão da incorporação dos atos internacionais ao sistema de direito positivo interno brasileiro. $\mathrm{O}$ exame da vigente Constituição Federal permite constatar que a execução dos tratados internacionais e a sua incorporação à ordem jurídica interna decorrem, no sistema adotado pelo Brasil, de um ato subjetivamente complexo, resultante da conjugação de duas vontades homogêneas: a do Congresso Nacional, que resolve, definitivamente, mediante decreto legislativo, sobre tratados, acordos ou atos internacionais (CF, art. 49, I) e a do Presidente da República, que, além de poder celebrar esses atos de direito internacional (CF, art. 84, VIII), também dispõe - enquanto Chefe de Estado que é - da competência para promulgá-los mediante decreto. O iter procedimental de incorporação dos tratados internacionais - superadas as fases prévias da celebração da convenção internacional, de sua aprovação congressional e da ratificação pelo Chefe de Estado - conclui-se com a expedição, pelo Presidente da República, de decreto, de cuja edição derivam três efeitos básicos que lhe são inerentes: (a) a promulgação do tratado internacional; (b) a publicação oficial de seu texto; e (c) a executoriedade do ato internacional, que passa, então, e somente então, a vincular e a obrigar no plano do direito positivo interno.

b) SUBORDINAÇÃO NORMATIVA DOS TRATADOS INTERNACIONAIS À CONSTITUIÇÃO DA REPÚBLICA - No sistema jurídico brasileiro, os tratados ou convenções internacionais estão hierarquicamente

$4 \quad$ Rapporteur. Min. Celso de Mello, jugement du 4.9.97. 
subordinados à autoridade normativa da Constituição da República. Em conseqüência, nenhum valor jurídico terão os tratados internacionais, que, incorporados ao sistema de direito positivo interno, transgredirem, formal ou materialmente, o texto da Carta Política. O exercício do treaty-making power, pelo Estado brasileiro - não obstante o polêmico art. 46 da Convenção de Viena sobre o Direito dos Tratados (ainda em curso de tramitação perante o Congresso Nacional) -, está sujeito à necessária observância das limitações jurídicas impostas pelo texto constitucional.

c) CONTROLE DE CONSTITUCIONALIDADE DE TRATADOS INTERNACIONAIS NO SISTEMA JURÍDICO BRASILEIRO. - O Poder Judiciário - fundado na supremacia da Constituição da República - dispõe de competência, para, quer em sede de fiscalização abstrata, quer no âmbito do controle difuso, efetuar o exame de constitucionalidade dos tratados ou convenções internacionais já incorporados ao sistema de direito positivo interno. Doutrina e Jurisprudência.

$\begin{array}{lcrr}\text { d) } & \text { PARIDADE } & \text { NORMATIVA } & \text { ENTRE } \\ \text { ATOS } & \text { INTERNACIONAIS } & \mathrm{E} & \text { NORMAS }\end{array}$

INFRACONSTITUCIONAIS DE DIREITO INTERNO.

- Os tratados ou convenções internacionais, uma vez regularmente incorporados ao direito interno, situam-se, no sistema jurídico brasileiro, nos mesmos planos de validade, de eficácia e de autoridade em que se posicionam as leis ordinárias, havendo, em conseqüência, entre estas e os atos de direito internacional público, mera relação de paridade normativa. Precedentes. No sistema jurídico brasileiro, os atos internacionais não dispõem de primazia hierárquica sobre as normas de direito interno. A eventual precedência dos tratados ou convenções internacionais sobre as regras infraconstitucionais de direito interno somente se justificará quando a situação de antinomia com o ordenamento doméstico impuser, para a solução do conflito, a aplicação alternativa do critério cronológico ("lex posterior derogat priori”) ou, quando cabível, do critério da especialidade. Precedentes. ${ }^{5}$

Observo que esse entendimento tradicional é de origem jurisprudencial. A Constituição brasileira não tem, quanto aos tratados internacionais em geral, uma regra clara como a do art. 55 da Constituição francesa:

\footnotetext{
Note-se que neste acórdão discutiu-se ainda a questão do cabimento de tratado em matéria constitucionalmente reservada à lei complementar. Esse ponto - central para a solução do caso, mas menos relevante para o presente estudo - foi decidido por maioria de votos pelo não cabimento, deferindo-se em parte a medida cautelar pleiteada, mediante interpretação conforme da referida Convenção.
} 
Les traités ou accords régulièrement ratifiés ou approuvés ont, dès leur publication, une autorité supérieure à celle des lois, sous réserve, pour chaque accord ou traité, de son application par l'autre partie.

Esse posicionamento do Supremo Tribunal Federal quanto à incorporação de tratados é objeto de reiterada jurisprudência, firmada desde a década de 70 do século passado.

No entanto, nos dias de hoje estamos em vias de presenciar uma importante alteração, que diz respeito não ao procedimento de incorporação em si, mas à posição hierárquica dos tratados no ordenamento jurídico interno brasileiro.

Essa alteração, porém, não se aplica a quaisquer tratados, mas àqueles que versem sobre direitos fundamentais.

Sobre o ponto da hierarquia dos tratados sobre direitos fundamentais, a doutrina - assim como a experiência de direito comparado - identifica quatro possíveis posições: a) os tratados possuem hierarquia supraconstitucional; b) os tratados possuem hierarquia constitucional; c) os tratados possuem hierarquia infraconstitucional, mas supralegal; d) os tratados possuem hierarquia de lei ordinária.

Como visto, esta última posição é a que tradicionalmente vem prevalecendo na jurisprudência constitucional brasileira nas últimas décadas. Mas vejamos o sentido da mudança que desponta.

Um primeiro aspecto dessa evolução não configura propriamente alteração de jurisprudência, mas da disciplina constitucional da matéria.

Emenda Constitucional n. 45/04, introduziu no art. $5^{\circ}$ de nossa Constituição $0 \oint 3^{\circ}$ :

Art. $5^{\circ}(\ldots) \S 3^{\circ}$. Os tratados e convenções internacionais sobre direitos humanos que forem aprovados, em cada Casa do Congresso Nacional, em dois turnos, por três quintos dos votos dos respectivos membros, serão equivalentes às emendas constitucionais.

Ou seja, caso o tratado sobre Direitos Humanos - e apenas um tratado com tal objeto - tenha seu processo de incorporação realizado de modo a respeitar o quorum de aprovação das emendas constitucionais, e ainda os dois turnos de votação em cada Casa do Congresso Nacional, seus dispositivos serão integrados ao Direito brasileiro com hierarquia de norma constitucional.

Esse dispositivo, de um lado, veio claramente negar as teses - o que, como visto, já era compreendido jurisprudencialmente - da automática hierarquia constitucional desses tratados; e quanto mais de sua eventual hierarquia supraconstitucional. Com efeito, apenas se incorporados por meio de procedimento análogo ao de emenda à Constituição é que terão status constitucional. 
De outro, porém, importa significativa evolução, abrindo a possibilidade de que ocorra a incorporação de tratados com hierarquia constitucional.

Mas o segundo aspecto da citada evolução - este sim importando verdadeiramente mudança na jurisprudência do Supremo Tribunal Federal.

Trata-se do RE 466.343. ${ }^{6}$ A discussão da questão de fundo invoca a Convenção Americana sobre os Direitos Humanos (Pacto de São José da Costa Rica), ratificada pelo Brasil em 1992 - que veda a prisão por dívida, salvo em caso de pensão alimentar (art. 7,7) - para sustentar a inconstitucionalidade da prisão civil do depositário infiel, particularmente no caso do contrato de alienação fiduciária em garantia.

E reiteradamente o Tribunal entendia não prevalecer a norma constante da convenção sobre o dispositivo constitucional brasileiro tal como interpretado.

Fornecer detalhes específicos da questão de fundo não seria interessante nesta ocasião. Aponte-se simplesmente que a Constituição brasileira, em seu art. $5^{\circ}$, LXVII, permite a prisão civil do depositário infiel. Ocorre, porém, que a lei que disiciplina a alienação fiduciária em garantia (Decreto-Lei n. 911/69) equipara a situação do devedor àqiela do depositário, o que leva à aplicação da norma da prisão civil a uma situação que - por um viés de argumentação com a qual concordo - não estaria prevista na hipótese constitucional.

Com o julgamento do RE 466.343 essa posição “pode ter” mudado. Explico o "pode ter".

O que se passa é que o STF, por unanimidade de votos, considerou inconstitucional a prisão civil por dívida do depositário infiel no caso da alienação fiduciária em garantia.

Mas agora é necessário que se abra um parêntese para uma explicação sobre o modo pelo qual o STF (e os tribunais em geral) decidem no Brasil.

Cada julgador - no caso do STF são 11 "Ministros" - tem total autonomia para proferir seu voto, oferecendo livremente as razões de decidir, e manifestando-se obiter dictum - sobre diversos assuntos.

A decisão do Tribunal, que se toma por maioria ou por unanimidade, formase tão somente quanto ao "dispositivo" do arrêt, ou seja, quanto à conclusão de ser ou não constitucional uma norma, ou de ser ou não procedente uma ação, ou de merecer ou não provimento um recurso.

Porém, não há nenhum modo pelo qual se uniformizam as razões de decidir. Sequer se pode considerar que as razões manifestadas no voto do Rapporteur são as que prevalecem.

6 Rel. Min. Cezar Peluso, j. 3.12.08, realizado em conjunto com o julgamento do RE n. 349.703, Rel. Min. Gilmar Mendes. 
Com todo respeito que tenho ao nosso STF e demais tribunais do País, ouso dizer que esse fato tem se tornado um problema para a segurança jurídica.

Isso porque, um acórdão de centenas de páginas, em que cada julgador mais se preocupa em externar sua visão subjetiva sobre questões jurídicas muitas vezes tomadas em abstrato, dificilmente dotará a decisão jurisdicional da objetividade que se exige do Direito, com vistas não apenas a solucionar um caso concreto, mas a balizar o tratamento de casos futuros.

Fechando o parêntese, pode-se considerar o julgamento ora analisado como um claro exemplo de decisão unânime - no caso, decidiu-se unanimemente pela inconstitucionalidade da prisão civil por dívida do depositário infiel - a qual, entretanto, parte de motivações absolutamente diversas.

Apenas para explicitar três linhas de argumentação que se delinearam com mais clareza, eu citaria os votos dos Ministros Cezar Peluso, que foi o relator deste caso, Gilmar Mendes e Celso de Mello.

O Ministro Cezar Peluso apresentou um argumento principal extraído da própria ordem jurídica interna do Brasil, independentemente de invocar a Convenção Americana sobre Direitos Humanos.

O Ministro parte da ideia de que a Constituição brasileira admite, como exceções, a prisão civil do dépositaire infidèle et du débiteur de pension alimentaire.

Já a norma legal que estende o caso de prisão ao devedor na alienação fiduciária em garantia, por equiparação com a situação do depositário infiel, estaria, inconstitucionalmente, valendo-se de uma ficção jurídica para ampliar o alcance de uma exceção constitucional. Isso implica uma mudança na tradicional jurisprudência do STF, que até então (desde a década de 60), não via inconstitucionalidade na medida.

Note-se que, por esse argumento, não entra em discussão a discrepância entre a Convenção Americana sobre Direitos Humanos e a Constituição brasileira: a primeira admitindo a prisão civil somente do devedor da pensão alimentar; a segunda, aceitando também a prisão civil do depositário infiel.

Aliás, o Ministro Cezar Peluso explicita não precisar invocar a Convenção Americana sobre Direitos Humanos para resolver o caso concreto em julgamento (sem que isso o tenha impedido de posteriormente adentrar no debate do assunto).

A seu turno, o Ministro Gilmar Mendes apresenta uma argumentação bastante inovadora quanto à posição do Tribunal em matéria de tratados sobre direitos humanos.

De plano, o Ministro afasta a tese da hierarquia constitucional dos tratatos, salvo no caso do $\S 3^{\circ}$ do art. $5^{\circ}$ da Constituição. Na sequência, apresenta argumentos contra a tese da hierarquia de lei ordinária dos tratados sobre direitos fundamentais.

Enfim, o Ministro passa a defender a tese da supralegalidade dos tratados sobre direitos fundamentais: 
Por conseguinte, parece mais consistente a interpretação que atribui a característica de supralegalidade aos tratados e convenções de direitos humanos. Essa tese pugna pelo argumento de que os tratados sobre direitos humanos seriam infraconstitucionais, porém, diante de seu caráter especial em relação aos demais atos normativos internacionais, também seriam dotados de um atributo de supralegalidade.

Em outros termos, os tratados sobre direitos humanos não poderiam afrontar a supremacia da Constituição, mas teriam lugar especial reservado no ordenamento jurídico. Equipará-los à legislação ordinária seria subestimar o seu valor especial no contexto do sistema de proteção dos direitos da pessoa humana. ${ }^{7}$

Esposando uma terceira posição, o Ministro Celso de Mello vota de modo a alterar sua própria posição em casos anteriores. Em suas próprias palavras:

Após muita reflexão sobre esse tema, e não obstante anteriores julgamentos desta Corte de que participei como Relator ${ }^{8}$, inclino-me a acolher essa orientação, que atribui natureza constitucional às convenções internacionais de direitos humanos, reconhecendo, para efeito de outorga dessa especial qualificação jurídica, tal como observa Celso Lafer, ${ }^{9}$ a existência de três distintas situações concernentes a referidos tratados internacionais:

1) tratados internacionais de direitos humanos celebrados pelo Brasil (ou aos quais o nosso País aderiu), e regularmente incorporados à ordem interna, em momento anterior ao da promulgação da Constituição de 1988 (tais convenções internacionais revestem-se de índole constitucional, porque formalmente recebidas, nessa condição, pelo $\S 2^{\circ}$ do art. $5^{\circ}$ da Constituição);

2) tratados internacionais de direitos humanos que venham a ser celebrados pelo Brasil (ou aos quais o nosso País venha a aderir) em data posterior à da promulgação da EC n. 45/2004 (essas convenções internacionais, para se impregnarem de natureza constitucional, deverão observar o iter procedimental estabelecido pelo $\S 3^{\circ}$ do art. $5^{\circ}$ da Constituição); e

$7 \quad$ Lembra, aliás, que a tese já havia sido recentemente ventilada no julgamento do RHC 79.785, julgado em 29.3.00, pelo então Relator Ministro Sepúlveda Pertence. Observa ainda que o Código Tributário Nacional já contém regra no sentido da prevalência dos tratados sobre o direito interno infraconstitucional, evidenciando uma incongruência, na medida em que o mesmo não se passava com a matéria dos direitos fundamentais.

8 E cita especialmente o já referido acórdão na ADI-MC 1.480.

9 A obra citada, em que Celso Lafer desenvolve em profundidade o raciocínio em questão, é: LAFER, Celso. A internacionalização dos direitos humanos: constituição, racismo e relações internacionais. Barueri: Manole, 2005. 
3) tratados internacionais de direitos humanos celebrados pelo Brasil (ou aos quais o nosso País aderiu) entre a promulgação da Constituição de 1988 e a superveniência da EC n. 45/2004 (referidos tratados assumem caráter materialmente constitucional, porque essa qualificada hierarquia jurídica lhes é transmitida por efeito de sua inclusão no bloco de constitucionalidade, que é "a somatória daquilo que se adiciona à Constituição escrita, em função dos valores e princípios nela consagrados" - [na expressão de Celso LAFER].

Já quanto às demais convenções internacionais, que não versem direitos humanos, o Ministro Celso de Mello mantém o entendimento tradicional do Supremo Tribunal, quanto a ingressarem no ordenamento jurídico interno brasileiro na mesma hierarquia de leis ordinárias.

Com esse panorama, lamento não poder ser mais preciso, esclarecendo a audiência qual a posição que pode ser considerada, enfim, a posição do Supremo Tribunal Federal sobre a matéria. Temos que aguardar casos futuros.

França, janeiro de 2012. 